\title{
Role of Cadre in Improving Knowledge and Attitude of Chronic Energy Deficiency on Teenagers in Mali-Mali Village, Banjar Regency, South Kalimantan, Indonesia
}

Meitria Syahadatina Noor ${ }^{1 *}$, Ayu Riana Sari ${ }^{2}$, R. Akbar Agustriyanto ${ }^{3}$, Rezeki Norwinardi $^{3}$, Diah Agustina ${ }^{3}$, Erma Rahmaniah $^{3}$, Erwinda Safitri ${ }^{3}$, Gusti Firdha Amalia ${ }^{3}$, Bohari Bohari ${ }^{4}$

${ }^{1}$ Department of Reproductive Health and Maternal-Child Health, Public Health Magister Program, Faculty of Medicine, Lambung Mangkurat University, City of Banjarmasin, Indonesia; ${ }^{2}$ Department of Health Policy, Public Health Study Program, Faculty of Medicine, Lambung Mangkurat University, City of Banjarmasin, Indonesia; ${ }^{3}$ Public Health Study Program, Faculty of Medicine, Lambung Mangkurat University, City of Banjarmasin, Indonesia; ${ }^{4}$ Department of Nutrition, Faculty of Medicine, Universitas Sultan Ageng Tirtayasa, City of Serang, Indonesia

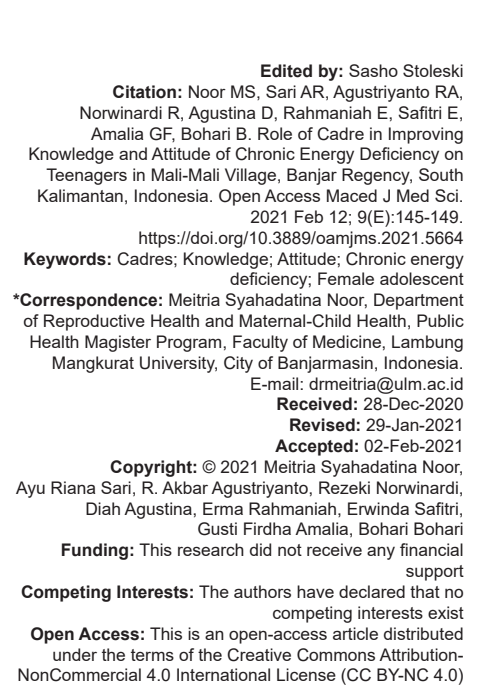

\begin{abstract}
AIM: The objective of this study was to analyze the role of cadres as an effort to increase knowledge and attitudes about chronic energy deficiency among adolescents in Mali-Mali village.

METHODS: This type of research is quasi experimental. Researchers trained five cadres who provide education to junior high school students. The sampling technique used a total sampling of 38 female students. The treatment duration was 4 months with the evaluation of knowledge, attitude, and upper arm circumference measurement each month.

RESULTS: This study's results were that $21.1 \%$ of respondents had good knowledge about chronic energy deficiency before treatment. The evaluation of respondents who had good knowledge about chronic energy deficiency at 1 month was $57.9 \%$. The $2^{\text {nd }}$ month was $294.7 \%$, the $3^{\text {rd }}$ month was $100 \%$, and the $4^{\text {th }}$ month was $100 \%$. Wilcoxon test showed a significant difference in knowledge at months 1,2 , and 3 with $p<0.05$. There was no significant difference at month 4 with a result of $p>0.05$. The evaluation results of respondents who had a good attitude about chronic energy deficiency before treatment were $26.3 \%$. In comparison, after treatment was $42.1 \%$ in the $1^{\text {st }}$ month, $57.9 \%$ in the $2^{\text {nd }}$ month, $57.9 \%$ in the $3^{\text {rd }}$ month, and $78.9 \%$ in the $4^{\text {th }}$ month. The Chi-square test results showed no differences in attitudes at month 1,2 , and 3 , while at month 4 found a significant relationship. The upper arm circumference measurement showed that the number of respondents who suffer from chronic energy deficiency was 25 people for 4 months.

CONCLUSION: Cadres could improve knowledge and attitudes about chronic energy deficiency in female
\end{abstract} adolescents in Mali-Mali Village.

\section{Introduction}

Chronic energy deficiency is a state of continuous lack of energy and protein intake in women of childbearing age and results in health problems. Meanwhile, according to Supariasa, Chronic Energy deficiency is a condition in which women experience malnutrition (calories and protein), which lasts for a long time. Chronic energy deficiency is characterized by measuring the upper arm circumference of $<23.5 \mathrm{~cm}$ [1].

According to Basic Health Research in 2018, the proportion of non-pregnant women who suffered chronic energy deficiency in Indonesia was $14.5 \%$. Meanwhile, the proportion of non-pregnant women experiencing chronic energy deficiency in South
Kalimantan province was $14.4 \%$ and the percentage of pregnant women with chronic energy deficiency was $18.2 \%$. Those are indicating that South Kalimantan's chronic energy deficiency was lower than Indonesia's. The proportion of women in the 15-19 age group who were not pregnant in 2018 was $36.3 \%$, indicating a decrease from 2013, which amounted to $46.6 \%$. However, compared to other age groups, women in the 15-19 age group have a higher proportion rate. Hence, it can be concluded that women in this age group have a higher risk than women in other age groups [2].

The percentage of not pregnant female adolescents is the highest among women with another work status, about $36 \%$. Basic Health Research also shows that non-pregnant women living in rural areas have a percentage of $15.3 \%$. That was higher than nonpregnant women living in urban areas [2]. 
In general, the proportion of women of childbearing age at risk of chronic energy deficiency is relatively high in adolescence (15-19 years) and decreases in the older age group. If the upper arm measurement is $<23.5 \mathrm{~cm}$, there is a risk of giving birth to a baby's low birth weight [3], [4]. This condition considers that women of childbearing age with a risk of chronic energy deficiency tend to give birth to babies with low birth weight. It inhibits growth within 5 years old and younger [5], [6].

The factors causing chronic energy deficiency in women of childbearing age and pregnant women are very complex, including an imbalance of nutritional intake, infection, or bleeding. The main group of women of childbearing age who are still included in the adolescent category is a group that is prone to experiencing chronic energy deficiency. Most teenagers have not met their daily nutritional needs, even though the energy they spend every day is quite a lot. Nutritional problems in adolescents will decrease the body's physical activity with good productivity, decreased physical fitness, and decreased hemoglobin levels [6], [7].

Data on people who experience chronic energy deficiency in Mali-Mali Village found that 20 people $(52.6 \%)$ had an upper arm circumference $<23.5 \mathrm{~cm}$. Among these girls, only $4.6 \%$ have good knowledge, while the rest have sufficient and less knowledge [8].

One of the factors that influence health behavior in Mali-Mali Village is knowledge. Lack of knowledge will lead to bad behavior. Increased knowledge can be provided through health education. Health education is provided with health promotion media's support to increase adolescent understanding [9], [10]. One technique that can be used to conduct health education in adolescents is by conducting counselor interventions [11]. Research by Syahadatina et al. proves that counselors can improve adolescent knowledge, attitudes, and the environment to change behavior [12]. Commonly, the counselor's research was conducted to change early marriage behavior. However, counselors/cadres' research to reduce the risk of chronic energy deficiency in adolescents was still not widely done.

The purpose of this study was to analyze the role of cadres as an effort to increase knowledge and attitudes about chronic energy deficiency among adolescents in Mali-Mali village.

\section{Methods}

This research method was quasi-experimental, with youth cadres' intervention to provide health education with leaflet media. This research involved 38 young women as samples selected by total sampling.
They were female students in Junior High School (SLTP)/equivalent in Mali-Mali Village who were willing to become respondents. This research was conducted in Mali-Mali Village, Karang Intan District, Banjar Regency, South Kalimantan, Indonesia.

The procedure carried out was to recruit five cadres chosen by the Head of Mali-Mali Village. Selected cadres were then given the training to provide information about chronic energy deficiency and skills of measuring upper arm circumference. Lecturers conducted the training at the Faculty of Medicine, University of Lambung Mangkurat. The health education program by cadres lasted for 4 months with leaflet media. Evaluation of knowledge, attitude, and upper arm circumference were evaluated 4 times.

The knowledge data analysis used was the paired T difference test with a confidence level of $95 \%$, if the data were normally distributed. If the data is not normally distributed, the Wilcoxon test would be carried out with a $95 \%$ confidence level. Attitude data were analyzed using the Chi-Square test with a confidence level of $95 \%$. Upper arm circumference data were analyzed descriptively.

Knowledge and attitudes were identified from the questionnaire. The number of questions for the knowledge and attitude questionnaire was 10 questions each. The questionnaire has been tested for validation and reliability. The upper arm circumference was measured with a measuring tape. This research was conducted in January-April 2018, in Mali-Mali Village. Data were collected by six enumerators who had been trained and equality of perceptions.

\section{Results}

The training was conducted by lecturers of the Faculty of Medicine, University of Lambung Mangkurat, to 5 female students at MTs Al-Khair, Mali-mali Village. The material given was about chronic energy deficiency and skills of measuring the upper arm circumference. The evaluation carried out was the knowledge and attitudes of young women about chronic energy deficiency.

Table 1 showed that female adolescents' knowledge had increased after providing health education for 4 months, with a frequency of $4 x$. Every month evaluation showed that young women with good knowledge always increase in the $1^{\text {st }}, 2^{\text {nd }}, 3^{\text {rd }}$, and $4^{\text {th }}$ months. In the past 2 months, all young women were categorized in good knowledge. Then, the results of attitude data are shown in Table 2.

Table 2 shows that changes in attitude were getting better related to chronic energy deficiency. The attitudes evaluated in 4 months had never decreased, 
Table 1: Knowledge of female adolescents before and after being given health education

\begin{tabular}{lllll}
\hline Knowledge category & Pre-test (\%) & Post-test 1 (\%) & Post-test 2 (\%) & Post-test 3 (\%) \\
\hline Good (75-100 points) & 21.1 & 57.9 & 94.7 & 100 \\
Enough (50-<75) & 73.7 & 39.5 & 5.3 & 0 \\
Less $(<50)$ & 5.3 & 2.6 & 0 & 0 \\
Total & 100 & 100 & 100 & 0 \\
\hline
\end{tabular}

Table 2: Adolescent attitudes before and after being given health education

\begin{tabular}{lllll}
\hline Attitude category & Pre-test (\%) & Post-test 1 (\%) & Post-test 2 (\%) & Post-test 3 (\%) \\
\hline Good & 26.3 & 42.1 & 57.9 & 57.9 \\
Bad & 73.7 & 57.9 & 42.1 & 72.1 \\
Total & 100 & 100 & 100 & 21.1 \\
\hline
\end{tabular}

although not all respondents had good attitudes regarding chronic energy deficiency.

All data in Table 1 were not normally distributed, so the difference test was continued with the Wilcoxon test with a confidence level of $95 \%$. The results of the statistical analysis of knowledge and attitudes are shown in Tables 3 and 4.

Table 3: Results of the Wilcoxon test statistics for knowledge data

\begin{tabular}{llllll}
\hline Variable & Pre-test & Pre-test & Pre-test & Pre-test & $\alpha$ - value \\
& Post-test 1 & Post-test 2 & Post-test 3 & Post-test 4 & \\
\hline Knowledge & 0.000 & 0.000 & 0.000 & 0.394 & 0.05 \\
\hline
\end{tabular}

Table 3 shows differences in respondents' knowledge before and after providing health education by cadres in the $1^{\text {st }}$ to the $3^{\text {rd }}$ month. However, there was no significant difference between respondents' knowledge about chronic energy deficiency before and after counseling at month 4 . It was due to the respondents' knowledge in the $3^{\text {rd }}$ and $4^{\text {th }}$ months was $100 \%$ classified as good.

Table 4: Chi-square test results for attitude data

\begin{tabular}{|c|c|c|c|c|c|c|c|}
\hline \multirow[t]{2}{*}{ Variable } & \multicolumn{2}{|c|}{ Attitude } & \multirow[t]{2}{*}{ Total } & \multirow[t]{2}{*}{ Df } & \multirow[t]{2}{*}{$\alpha$-value } & \multirow[t]{2}{*}{ X2 Table } & \multirow[t]{2}{*}{ X2 Count } \\
\hline & Good & Bad & & & & & \\
\hline \multicolumn{8}{|l|}{ Test 1} \\
\hline Post test & 16 & 22 & 38 & 1 & 0.05 & 3.841 & 2.464 \\
\hline Pre-test & 10 & 28 & 38 & & & & \\
\hline Total & 26 & 50 & 76 & & & & \\
\hline \multicolumn{8}{|l|}{ Test 2} \\
\hline Post-test & 22 & 16 & 38 & 1 & 0.05 & 3.841 & 1.896 \\
\hline Pre-test & 16 & 22 & 38 & & & & \\
\hline Total & 38 & 38 & 76 & & & & \\
\hline \multicolumn{8}{|l|}{ Test 3} \\
\hline Post test & 22 & 16 & 38 & 1 & 0.05 & 3.841 & 1.896 \\
\hline Pre-test & 16 & 22 & 38 & & & & \\
\hline Total & 38 & 38 & 76 & & & & \\
\hline \multicolumn{8}{|l|}{ Test 4} \\
\hline Post-test & 30 & 8 & 38 & 1 & 0.05 & 3.841 & 3.896 \\
\hline Pre-test & 22 & 16 & 38 & & & & \\
\hline Total & 52 & 24 & 76 & & & & \\
\hline
\end{tabular}

Table 4 shows no significant differences in attitudes before and after health education by cadres at months 1-3. However, there was a significant difference in month 4. Another variable assessed based on the cadre's skills was the circumference of the upper arm. The data on the upper arm circumference measured every month are presented in Table 5 . Table 5 shows the same upper arm circumference data for the 4 months of evaluation. Thus, the data were not subjected to statistical analysis.

Table 5: Data on upper arm circumference of the female adolescent in Mali-Mali Village

\begin{tabular}{lllll}
\hline Chronic energy deficiency category & $1^{\text {st }}$ Month & $2^{\text {nd }}$ Month & $3^{\text {td }}$ Month & $4^{\text {th }}$ Month \\
\hline Chronic energy deficiency & 25 & 25 & 25 & 25 \\
Normal & 13 & 13 & 13 & 13 \\
Total & 38 & 38 & 38 & 38 \\
\hline
\end{tabular}

\section{Discussion}

Statistical results for analyzing the role of health education by cadres on respondents' knowledge of chronic energy deficiency were subjected to different tests. The results of the analysis (Table 3 ) showed that health education by cadres had a significant role in increasing respondents' knowledge about chronic energy deficiency $(p<0.05)$. It was supported by descriptive data in Table 1, which shows an increase in respondents with good knowledge of chronic energy deficiency in each evaluation period. There are differences in knowledge and attitudes before and after the intervention but have not had an impact on the circumference of the upper arm because the circumference of the upper arm is a long-term nutritional indicator that will change in a long time. In addition, the factors that affect the circumference of the upper arm can come from other factors, namely, diet, family economic status, and other environmental factors that affect the nutritional intake of these adolescents which were not identified in this study.

Health education plays a role in the implementation of health services, disease prevention, and health promotion. Health education aims to improve disease prevention by increasing health knowledge and behavior [13], [14], [15]. The effectiveness of cadres can be evaluated through increasing respondents' knowledge after receiving health education from trained cadres [16]. It is in line with the research results presented in Table 1.

Knowledge is various matters obtained through the five senses [17]. Knowledge has different intensities. There are six levels of knowledge: (1) Knowledge, the respondent can only recall the information obtained; (2) comprehension, the respondent understands an object, not only mentions it but also interprets it correctly; (3) application, people who have understood information can apply it in life; (4) analysis, the ability to describe and separate, then look for relationships between the components contained in an object; (5) synthesis, the ability to summarize a logical relationship from the components of the knowledge possessed; and (6) evaluation, the ability in judging based on applicable criteria or norms [17].

One of the factors that influence a person's knowledge is the environment. The environment is 
everything around the individual. The environment affects the process of entering knowledge into the individuals in that environment. It happens due to the reciprocal interaction that will be responded to as knowledge [17]. One of the environmental factors is cadres who interact with specific community groups to provide health knowledge interactions.

The village head selects cadres based on their activeness and social skills with adolescents, then conducts training by providing information about Chronic Energy Deficiency and how to measure upper arm circumference. Cadres can play a role in improving nutritional status by providing counseling. The trained cadres would have better knowledge. Hence, they can provide information to respondents. The expected output is a change in behavior related to an increase in nutritional status [18].

Health education can be facilitated by using the media. The media used in this study were leaflets. The leaflet is a short publication in the form of a leaflet containing information or information. The advantages of leaflets are that they are attractive, easy to understand, and concise [19]. The right knowledge will affect a person's attitude. Attitude is an emotional predisposition to respond to an object [20]. Attitudes are certain regularities in terms of feelings (affection), thoughts (cognitive), and actions predisposition towards an aspect of the surrounding environment [17]. In this study, the respondents' knowledge increased to have good knowledge about chronic energy deficiency in months 3 and 4 . This knowledge made respondents' attitudes toward chronic energy deficiency also improved in months 4 (Tables 1 and 2). It is because the process of someone becoming aware and responding takes time.

In this study, the stages of knowledge that the respondent had after health education were at levels 1-2 because it had improved attitudes but had not changed the nutritional status of the respondent. The measured nutritional status of respondents is the circumference of the upper arm. The number of respondents who experience chronic energy deficiency is still the same every month. There has not been a decrease. Since the upper arm's circumference is an indicator of nutrition, that will change in the long term. The health impact of this research is that cadres' assistance in providing information about chronic energy deficiency can increase adolescent knowledge and attitudes about chronic energy deficiency so that it is expected to have an impact on adolescent behavior changes such as diet to reduce the incidence of chronic energy deficiency. The strength of this study is that it uses community empowerment in helping the government to overcome nutritional problems for girls. The limitation of this study is that the evaluation only lasts for 3 months, while upper arm circumference is a nutritional parameter that will change in a long time.

\section{Conclusion}

The role of cadres could increase knowledge and attitudes about chronic energy deficiency in adolescents in Mali-Mali village. Based on this study's results, it can be suggested to conduct regular training for health cadres to provide information about chronic energy deficiency and measure the upper arm circumference to detect adolescent women's nutritional status early. Health information should be continuously given because changes in knowledge, attitudes are related to chronic energy deficiency would take time. Hence, it will reduce the incidence of chronic energy deficiency in young girls.

\section{References}

1. Petrika $\mathrm{Y}$, Hadi $\mathrm{H}$, Nurdiati DS. Tingkat asupan energ dan ketersediaan pangan berhubungan dengan risiko kekurangan energi kronik (KEK) pada ibu hamil. J Gizi Diet Indones. 2016;2(3):140-9. https://doi.org/10.21927/ ijnd.2014.2(3).140-149

2. Kementerian Kesehatan Republik Indonesia. Riset Kesehatan Dasar 2018. Jakarta: Kementerian Kesehatan Republik Indonesia; 2018. https://doi.org/10.6066/jtip.2013.24.2.121

3. Ahankari AS, Myles PR, Dixit JV, Tata LJ, Fogarty AW. Risk factors for maternal anaemia and low birth weight in pregnant women living in rural India: A prospective cohort study. Public Health. 2017;151:63-73. https://doi.org/10.1016/j. puhe.2017.06.023

PMid:28743049

4. Elizabeth NL, Christopher OG, Patrick K. Determining an anthropometric surrogate measure for identifying low birth weight babies in Uganda: A hospital-based cross sectional study. BMC Pediatr. 2013;13(1):54. https://doi. org/10.1186/1471-2431-13-54

PMid:23587297

5. Arista AD, Widajanti L, Aruben R. Relationship of knowledge, attitudes, levels of energy consumption, protein, and body mass index / age with chronic energy deficiency in young girls (study in Islamic vocational high school baiturrahman center Semarang during the fasting month of Ramadan in 2017. J Kesehatan Masyarakat (Undip). 2017;5(4):585-591.

6. Wardhani JP, Rahfiludin MZ, Pradigdo SF. Differences in physical activity, hemoglobin, and physical fitness (a study of students with less chronic energy and no chronic energy deficiency in SMA N 1 grogol, Kediri district. J Kesehatan Masyarakat (Undip). 2017;3(3):205-212.

7. Zaki I, Sari EP, Farida F. Asupan zat gizi makro dan lingkar lengan atas pada remaja putri di kawasan perdesaan Kabupaten Banyumas. Prosiding. 2017;7(1):435-41. Available from: http://www.jurnal.Ippm.unsoed.ac.id/ojs/index.php/Prosiding/ article/view/535. [Last accessed on 2020 Dec 26]. https://doi. org/10.20884/1.jgps.2018.2.1.420

8. Agustriyanto RA. Laporan Pelaksanaan Pengalaman Belajar Lapangan 1 Di Desa Mali Mali Kecamatan Karang Intan Kabupaten Banjar: Pembentukan Kader Dan Penyuluhan Kesehatan Serta Pengukuran Lila Sebagai Solusi Masalah Kek Pada Remaja Puteri Di Desa Mali-Mali. Banjarbaru: Program Studi Kesehatan Masyarakat Fakultas Kedokteran Unlam; 
2018. https://doi.org/10.31602/as.v2i2.1180

9. Mubarak WI. Promosi Kesehatan: Sebuah Pengantar Proses Belajar Mengajar dalam Pendidikan. Yogyakarta: Graha IImu; 2007.

10. Stellefson M, Paige SR, Chaney BH, Chaney JD. Evolving role of social media in health promotion: Updated responsibilities for health education specialists. Int J Environ Res Public Health. 2020;17(4):1153. https://doi.org/10.3390/ijerph17041153 PMid:32059561

11. Slyter M. Creative counseling interventions for grieving adolescents. J Creat Ment Health. 2012;7(1):17-34.

12. Syahadatina N, Rahayu A, Rahman F, Yulidasari F, Rosadi D, Laily $\mathrm{N}$, et al. Development of "young planning clinic" program as a prevention early in adolescent attitude in Martapura river areas. Indian J Public Health Res Dev. 2020;11:189. https://doi. org/10.37506/v11/i1/2020/ijphrd/194151

13. Golden SD, Earp JA. Social ecological approaches to individuals and their contexts: Twenty years of health education \& behavior health promotion interventions. Health Educ Behav. 2012;39(3):364-72. https://doi.org/10.1177/1090198111418634 PMid:22267868

14. Paixão MM, Ballouz T, Lindahl JF. Effect of education on improving knowledge and behavior for arboviral diseases: A systematic review and meta-analysis. Am J Trop Med Hyg.
2019;101(2):441-7. https://doi.org/10.4269/ajtmh.19-0170

PMid:31115297

15. Wang $\mathrm{M}$, Han $\mathrm{X}$, Fang $\mathrm{H}, \mathrm{Xu} \mathrm{C}$, Lin $\mathrm{X}, \mathrm{Xia} \mathrm{S}$, et al. Impact of health education on knowledge and behaviors toward infectious diseases among students in Gansu Province, China. Biomed Res Int. 2018;2018:6397340. https://doi.org/10.1155/2018/6397340 PMid:29707573

16. Hadiyanta TH, Istiono W, Pramantara ID. Impact of Training by Family Doctor on Cadre Performance in Counseling at Posbindu Dusun Tahunan of Gunungkidul Regency. Rev Prim Care Pract Educ. 2018;1(1):31-7. https://doi.org/10.22146/rpcpe.33884

17. Notoatmodjo S. IImu Perilaku Kesehatan. Jakarta: Penerbit Rineka Cipta; 2014.

18. Irwan Z, Faturrahman F, Muslimin I. Performance of integrated healthcare center cadre and scope of community participation. Indones J Glob Health Res. 2019;1(1):73-80. https://doi. org/10.37287/ijghr.v1i1.3

19. Maulana MA. Pengembangan Media Pembelajaran Leaflet. Makassar: Universitas Islam Negeri Alaudin Makassar; 2017.

20. Zhu X, Xie X. Effects of knowledge on attitude formation and change toward genetically modified foods. Risk Anal. 2015;35(5):790-810. https://doi.org/10.1111/risa.12319 PMid:25693867 